\title{
Further Evidence for an Association of 5-HTTLPR with Intensity Dependence of Auditory-Evoked Potentials
}

\author{
Tilman Hensch*,', Hanna-Linn Wargelius², Ulf Herold', Klaus-Peter Lesch ${ }^{3}$, Lars Oreland ${ }^{2}$ \\ and Burkhard Brocke' \\ 'Department of Psychology, Dresden University of Technology, Dresden, Germany; ${ }^{2}$ Department of Neuroscience, Section of Pharmacology, \\ Uppsala University, Uppsala, Sweden; ${ }^{3}$ Department of Psychiatry and Psychotherapy, University of Würzburg, Würzburg, Germany
}

\begin{abstract}
Intensity dependence of auditory-evoked potentials (IAEP) has been suggested as an indicator of central serotonergic neurotransmission. Two recent studies investigated a possible association of IAEP with a functional polymorphism in the transcriptional control region of the serotonin transporter gene (5-HTTLPR) that has a short (s) and a long (I) variant. Although both studies found an association between 5-HTTLPR and IAEP, Gallinat et al found I/I individuals to exhibit lower IAEP, whereas Strobel et al observed stronger IAEP in I/I individuals. These conflicting results require further evaluation and more attention needs to be paid to variables that are known to be confounded with the effects of IAEP and 5-HTTLPR. Using a paradigm comparable to Strobel et al, the present study analyzes the effect of 5-HTTLPR on IAEP in a healthy male student sample $(N=9$ l; age $=23$ years, $S D=1.9)$ that was homogenous for most significant confounding variables. A stronger IAEP was shown in I/I individuals, irrespective of the method of IAEP parametrization. This also held at retest after 3 weeks in a subsample $(N=18)$. Given the successful replication of Strobel et al, several possible reasons for conflicting results with regard to Gallinat et al are discussed. It is argued that the most significant difference between Gallinat et al on the one hand, and Strobel et al and this study on the other, is that different intensity ranges are used which impact IAEP. Therefore, this study encourages further analysis of dose dependence of results.

Neuropsychopharmacology (2006) 31, 2047-2054. doi:10.1038/sj.npp. I 30 I020; published online 18 January 2006
\end{abstract}

Keywords: serotonin transporter; genetic polymorphism; 5-HTTLPR; endophenotype; auditory-evoked potentials; intensity dependence

\section{INTRODUCTION}

Serotonergic neurotransmission is involved in several psychiatric disorders and is an important target of pharmacotherapeutic interventions. Therefore, valid and reliable indicators of central serotonergic function are of great importance.

Intensity dependence of auditory-evoked potentials (IAEP) has been suggested as a noninvasive indicator of central serotonergic neurotransmission (Hegerl and Juckel, 1993). A strong increase in amplitudes of the auditory N1/P2 component, that is, a strong N1/P2 IAEP, is thought to reflect low serotonergic activity and vice versa.

Animal studies have revealed that reducing or increasing serotonergic activity increases or decreases N1/P2 IAEP in the primary auditory cortex (Juckel et al, 1999, 1997).

\footnotetext{
*Correspondence: T Hensch, Department of Psychology, Dresden University of Technology, Mommsenstr. 13, Dresden 01062, Germany, Tel: + 49 35I 463 36999, Fax: + 4935 I 463 36993,

E-mail: Tilman.Hensch@tu-dresden.de

Received II July 2005; revised 4 November 2005; accepted 28 November 2005

Online publication: I December 2005 at http://www.acnp.org/citations/ Npp I20105050445/default.pdf
}

Moreover, several studies on clinical samples have lent indirect support to the hypothesis that N1/P2 IAEP is related to serotonergic neurotransmission: Higher N1/P2 IAEP was observed in patients with a better treatment response to selective serotonin reuptake inhibitors (SSRI) or lithium (Gallinat et al, 2000; Hegerl et al, 2001; Juckel et al, 2004; Lee et al, 2005) and the severity of drug-induced serotonin syndrome has been shown to be related to lower N1/P2 IAEP (Hegerl et al, 1998). Furthermore, IAEP has emerged to be positively correlated with personality traits like impulsivity and sensation seeking, which are thought to be characterized by low serotonergic neurotransmission (Brocke et al, 1999; Hegerl et al, 1995; Zuckerman, 1994). In patients with supposed serotonergic dysfunction (migraine patients, bipolar affective disorder patients, and Ecstasy users), high IAEP has been observed (Brocke et al, 2000; Croft et al, 2001; Siniatchkin et al, 2000; Tuchtenhagen et al, 2000).

Serotonergic medications altered IAEP in some studies in humans (Proietti-Cecchini et al, 1997; Roon et al, 1999). To date, however, most attempts to directly test the hypothesis that serotonin modulates IAEP in humans by manipulating serotonergic neurotransmission with acute tryptophan depletion (ATD) have failed or their results have been 
contrary to expectations (Debener et al, 2002; Dierks et al, 1999; Kähkönen et al, 2002; Massey et al, 2004). These findings support the notion that it is difficult to predict the effects of ATD on IAEP. On the one hand, ATD causes reduced serotonin availability in the cortex (Nishizawa et al, 1997); on the other hand, this is immediately followed by adaptive receptor and transporter changes (eg Milak et al, 2005; Yatham et al, 2001). Considering these problems, naturally occurring (eg genetically driven) interindividual differences in serotonergic function may provide a promising context for indirect validation of IAEP.

The serotonin transporter plays a pivotal role in serotonergic function (Lesch and Mössner, 1998). In recent years, much research has been conducted on the serotonin transporter gene-linked polymorphic region (5-HTTLPR), a functional length variation in the transcriptional control region of the serotonin transporter gene that has a short (s) and a long (l) variant. The 5-HTTLPR s allele has proved to be associated with traits assumed to be modulated by serotonin, such as anxiety-related traits, in several studies (Schinka et al, 2004; Sen et al, 2004). It is also related to stress susceptibility (Caspi et al, 2003) and psychiatric disorders that involve serotonergic dysfunction; for example, affective disorders (Lasky-Su et al, 2005; Lotrich and Pollock, 2004) and alcohol dependence (Feinn et al, 2005; Nilsson et al, 2005). Furthermore, the s allele is associated with lower response to serotonergic agents (Moreno et al, 2002; Perna et al, in press; Smits et al, 2004). However, complex behavior is modulated by multiple genes interacting with one another and with diverse environmental influences across the lifespan. Therefore, the effect of a single polymorphism on complex behavior will usually be small (Reif and Lesch, 2003) and difficult to detect. A promising approach is thus to assess the effects of genes on more direct biological indices of serotonergic function (Hariri and Weinberger, 2003). To date, the 5-HTTLPR s allele has been successfully related to lower CSF-serotonin metabolites (Williams et al, 2003), to lower prolactin response in serotonergic drug challenge studies (Reist et al, 2001; Smith et al, 2004; Whale et al, 2000), to lower brain-derived neurotrophic factor (Lang et al, 2005), to stronger amygdala response in brain-imaging studies (Furmark et al, 2004; Hariri et al, 2002, 2005; Heinz et al, 2005; Pezawas et al, 2005), to lower hippocampal $N$-acetylaspartate (Gallinat et al, 2005), to better acquisition of fear conditioning as measured by skin conductance response (Garpenstrand et al, 2001), and to electrophysiological indices of motor control and error processing (Fallgatter et al, 1999, 2004).

So far, only two studies have related 5-HTTLPR to IAEP. Although both found an association between 5-HTTLPR and IAEP, supporting the hypothesis that serotonergic function is involved in the modulation of IAEP, Gallinat et al (2003) found $1 / 1$ individuals to exhibit lower IAEP, whereas Strobel et al (2003) observed stronger IAEP in 1/1 individuals.

At present, it is difficult to make a clear prediction of which genotype will be associated with higher IAEP. In vitro studies of non-neural cells showed higher transcriptional activity and higher serotonin reuptake of the 1 allele (Greenberg et al, 1999; Lesch et al, 1996). Postmortembinding studies and three recent SPECT studies produced conflicting results, however (Willeit et al, 2001; for other studies see an overview in van Dyck et al, 2004). Assuming that $s$ allele carriers have a less efficient serotonin transporter, more serotonin should be left in the synaptic cleft, as has been shown in a mouse model (Holmes et al, 2003). This high serotonin availability in s allele carriers could result in low IAEP (Manjarrez et al, 2001) in line with the findings of Strobel et al (2003). Yet there are also reasons for predicting the opposite: Given the impaired ability of the $s$ allele for rapid reuptake of serotonin from the synaptic cleft, it has been suggested that a $5-\mathrm{HT}_{1 \mathrm{a}}$ receptor-mediated negative feedback mechanism ultimately results in a decreased serotonergic firing rate (Lesch and Mössner, 1998). This decrease in firing rate in $s$ allele carriers could lead to high IAEP. On the other hand, changes in neurotransmission are normally accompanied by up- or downregulation of receptors, such as the postsynaptic $5-\mathrm{HT}_{1 \mathrm{~A}}$ and $5-\mathrm{HT}_{2}$ receptors, both of which may be involved in IAEP (Juckel et al, 1997, 2003). In conclusion, then, it is difficult to predict the net effect of serotonin levels in the synaptic cleft, the raphe firing rate, and adaptive processes in pre- and postsynaptic receptors on IAEP.

Moreover, the influence of 5-HTTLPR on IAEP could simply be the result of genotype-driven differential development, for example, of the auditory system, and might not necessarily reflect acute monoamine status. There is evidence that serotonin transporter alterations act in early developmental phases (Ansorge et al, 2004; Maciag et al, in press; Pezawas et al, 2005).

Thus, as long as it remains difficult to make directional bottom-up predictions from gene (5-HTTLPR) to endophenotype (IAEP), replications are needed to clarify which genotype is in fact related to high IAEP. Such studies with nondirectional hypotheses should primarily consider variables that are known to be confounded with the effects of IAEP and 5-HTTLPR. To this end, the present study analyzes the effect of 5-HTTLPR on IAEP in a sample that was homogenous for most significant confounding variables. A further objective of this study is to test the stability of results against several different IAEP parametrizations used in literature. This is done to rule out the possibility of different methods of IAEP parametrization producing conflicting results.

\section{METHODS}

\section{Subjects}

A total of 91 healthy right-handed Caucasian nonsmoking male students between 19 and 27 years of age (mean $=23.3$; $\mathrm{SD}=1.9$ ) met the following inclusion criteria and participated in the study. The inclusion criteria were applied to control or keep constant major confounding factors that are related to either 5-HTTLPR genotype or serotonergic neurotransmission, or that have a strong impact on auditory-evoked potentials (AEPs). As gender influences serotonergic neurotransmission, as with gender-specific effects of serotonin transporter alterations, for example (Amin et al, 2005; Barr et al, 2004b; Bouali et al, 2003; Currie et al, 2004; Dominguez et al, 2003; Halbreich et al, 1995; Nishizawa et al, 1997; Rubinow et al, 1998; Williams et al, 2003), and because gender also impacts IAEP 
(Bruneau et al, 1986; Camposano and Lolas, 1992; Schwerdtfeger and Baltissen, 1999; Silverman et al, 1973), only male subjects were included in the sample. Sampling a female population would have increased the sample size unreasonably, as it would have then been necessary to control the effects of the menstrual cycle and contraceptives on AEPs (Walpurger et al, 2004). As age is also correlated with serotonergic function (Tauscher et al, 2001) and with IAEP (Hegerl et al, 1994; Siniatchkin et al, 2000), only a narrow age range was sampled. In addition, because smoking alters serotonergic neurotransmission (Seth et al, 2002) and because smoking behavior is related to 5HTTLPR (Gerra et al, 2005; Kremer et al, 2005), only nonsmokers were included. According to written selfreports, 75 of the subjects had never smoked and 16 had stopped smoking, 10 of them more than 1 year ago and the remaining six at least 2 months ago. Furthermore, subjects had to be free of any psychiatric or neurological disorder thought to be influenced by serotonergic neurotransmission (especially migraine and affective or anxiety disorders). Centrally acting medications or casual use of drugs (Ecstasy in particular) were further exclusion criteria. Subjects were asked about these exclusion criteria twice: At an initial telephone interview and again via a questionnaire in the laboratory. Normal hearing was verified by means of audiometry.

Participants were paid and gave written informed consent. The study was conducted in accordance with the Ethics Commission of the University of Dresden and the Declaration of Helsinki.

\section{EEG Recording}

EEG recording was performed with eyes open in an acoustically and electrically shielded room (IAC, Niederkrüchten, Germany). No attention or vigilance instruction was given. The subjects were told only to avoid body movements and to lightly fixate a point in front of them in order to reduce alpha artifacts and eye movements. EEG was recorded with $\mathrm{Ag} / \mathrm{AgCl}$ electrodes at $\mathrm{Cz}, \mathrm{C} 3$, and $\mathrm{C} 4$, with the nose tip as the reference point and $\mathrm{AFz}$ as ground. Additionally, a vertical and a horizontal electro-oculogram was recorded to monitor ocular artifacts. Impedances were kept below $8 \mathrm{k} \Omega$ with less than $0.5 \mathrm{k} \Omega$ difference between single electrodes. EEGs were continuously recorded with a Synamps 4.1 amplifier (NeuroScan Inc., El Paso, TX, USA) at a digitization rate of $1000 \mathrm{~Hz}$. Calibrated sinus tones $(1000 \mathrm{~Hz}, 30 \mathrm{~ms}$ duration with $10 \mathrm{~ms}$ rise and $10 \mathrm{~ms}$ fall time) of six intensities $(66,72,78,84,90,96 \mathrm{~dB}$ SPL) were presented binaurally via Eartone $3 \mathrm{~A}$ Audiometric Insert Earphones (Aearo Company, Indianapolis, IN, USA) in pseudo-randomized order. Presentation 0.80 (Neurobehavioral Systems Inc., Albany, CA, USA) was used to present the sounds. Simultaneity of trigger and sound was verified using SCLA (Neurobehavioral Systems). Each intensity level was repeated 108 times and the interstimulus interval varied pseudo-randomly between 1600 and $2100 \mathrm{~ms}$.

\section{EEG Analysis}

AEP analysis was performed with Brain Vision Analyzer 1.04 (Brain Products GmbH, Munich, Germany). EEGs were epoched off-line into sweeps of $600 \mathrm{~ms}$, starting $200 \mathrm{~ms}$ prior to stimulus onset. In line with previous studies (Brocke et al, 2000), a digital offline bandpass filter from 0.1 to $30 \mathrm{~Hz}$ was used. All sweeps with a voltage exceeding $\pm 50 \mu \mathrm{V}$ in any of the channels were excluded from averaging. This resulted in a mean of 77 accepted sweeps per intensity level. The number of accepted sweeps did not differ across the six intensity levels.

Baseline to peak amplitudes of AEPs were automatically derived for N1 (55-160 ms) and P2 (110-260 ms), and N1/P2 peak-to-peak amplitudes were then calculated. To test the assumption of a linear increase in amplitudes over intensity levels, a repeated measurement analysis of variance was performed with intensity level (six intensities) and position $(\mathrm{Cz}, \mathrm{C} 3, \mathrm{C} 4)$ as repeated measures and age as covariate. Since a significant linear trend was observed $(p=0.001)$, the individual intensity dependence was calculated as the slope of the linear regression of amplitudes against stimulus intensities (known as the amplitude-stimulus function slope or ASF slope).

In order to further evaluate the results, alternative parametrizations of IAEP were calculated. Following Strobel et al (2003), a nonlinear calculation of IAEP was performed based on the median of the 15 slopes between all possible pairs of the six amplitude values. This slope (called median slope) does not require linearity of IAEP. Calculating ASF and median slopes based on peaks of AEP components still entails the problem of multiple peaks within a single AEP component, however. ASF and median slopes were therefore also calculated using the whole area under the EEG curve within a window of the AEP component drawn from grand averages (N1: 65-145 ms; P2: 130-230 ms). Finally, because calculating a slope only partly reflects individual variability in amplitudes at the six intensity levels, all six amplitudes were entered directly in a repeated measures analysis of variance with intensity level (six intensities) and position $(\mathrm{Cz}, \mathrm{C} 3, \mathrm{C} 4)$ as repeated measures and age as covariate.

\section{Genotyping}

DNA was extracted from venous blood, and with regard to the 5-HTTLPR polymorphism, PCR-based genotyping was performed according to a modified protocol by Collier et al (1996). In order to confirm that the correct region of the serotonin transporter gene was amplified, PCR products representing all genotypes were sequenced using BigDye ${ }^{\circledR}$ Terminator chemistry (Applied Biosystems) and analyzed by an automated ABI PRISM ${ }^{\mathrm{TM}}$ (Perkin Elmer, Foster City, CA, USA). The DNA fragments were analyzed using the Sequencer $^{\mathrm{TM}}$ 3.1.1 software.

\section{RESULTS}

At $40.7 \%$ for the s allele and $59.3 \%$ for the 1 allele, the allele frequencies of 5-HTTLPR were comparable with other studies on European subjects. The genotype distribution of study subjects $(1 / 1=29(32 \%), s / l=50 \quad(55 \%), s / s=12$ $(13 \%))$ is in Hardy-Weinberg equilibrium. The IAEP function of each genotype is plotted in Figure 1. 


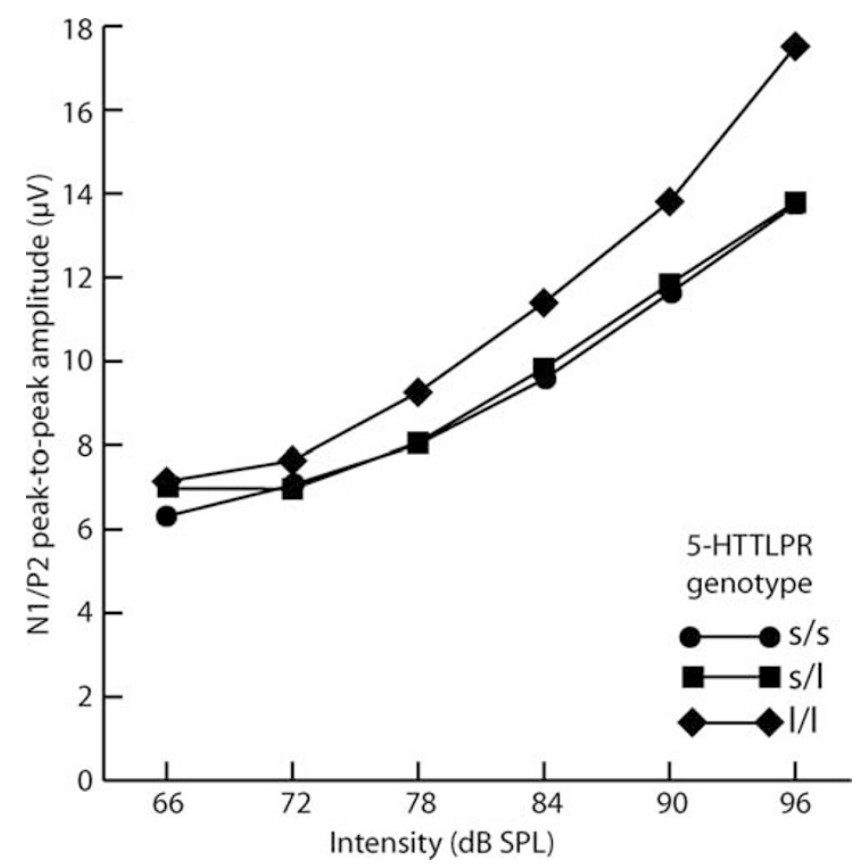

Figure I IAEP function at central sites (Cz, C3, C4) for each 5-HTTLPR genotype group (s/s, s/l, I/I).

The association of 5-HTTLPR genotype with IAEP slope was analyzed in a repeated measures analysis of variance with electrode position $(\mathrm{C} 3, \mathrm{C} 4, \mathrm{Cz})$ as withinsubjects factor, 5-HTTLPR genotype (1/1 vs s/l vs s/s) as between-subjects factor, and age as covariate. There was a significant main effect of 5-HTTLPR on ASF slope $\left(\mathrm{F}_{2,87}=4.796 ; p=0.011\right)$, accounting for $10 \%$ of the variance $\left(\eta^{2}=0.099\right)$. Bonferroni-corrected post hoc tests revealed that the 5-HTTLPR $1 / 1$ genotype was associated with higher ASF slopes than the s/l genotype ( $p=0.013$; Figure 2 ). The main effects for age and position and the interaction of age and position did not reach significance level, but a significant interaction of 5-HTTLPR and position emerged, with $\mathrm{Cz}$ having stronger IAEP $\left(\mathrm{F}_{3.4,149.1}=3.346\right.$; $p=0.016)$.

Further analyses were performed to confirm these results in greater detail: Median slopes correlated highly with ASF slopes (Cz: $r=0.94$; C3 $r=0.96$; C4: $r=0.93$; all $p<0.0001$ ). Entering median instead of ASF slopes in repeated measures analysis of variance corroborated the results (main effect of 5-HTTLPR: $\mathrm{F}_{2,87}=5.456 ; p=0.006$ ).

In order to avoid the problem of multiple peaks in AEP components, ASF and median slopes were also calculated using the whole area under the EEG curve instead of a single peak. Again, this revealed a significant main effect of 5-HTTLPR on IAEP (area of ASF slope: $\mathrm{F}_{2,87}=5.326$; $p=0.007$; area of median slope: $\mathrm{F}_{2,87}=6.410 ; p=0.003$ ).

Apart from calculating ASF and median slopes, individual amplitude values were directly entered in a repeated measures analysis of variance with intensity level (six intensities) and position ( $\mathrm{Cz}, \mathrm{C} 3, \mathrm{C} 4)$ as repeated measures and age as covariate. These analyses also revealed significant interactions of 5-HTTLPR with intensity level (peaks: $\mathrm{F}_{4.5,196.3}=2.932 ; p=0.017 ;$ areas: $\mathrm{F}_{4.5,193.7}=3.584$; $p=0.006)$.

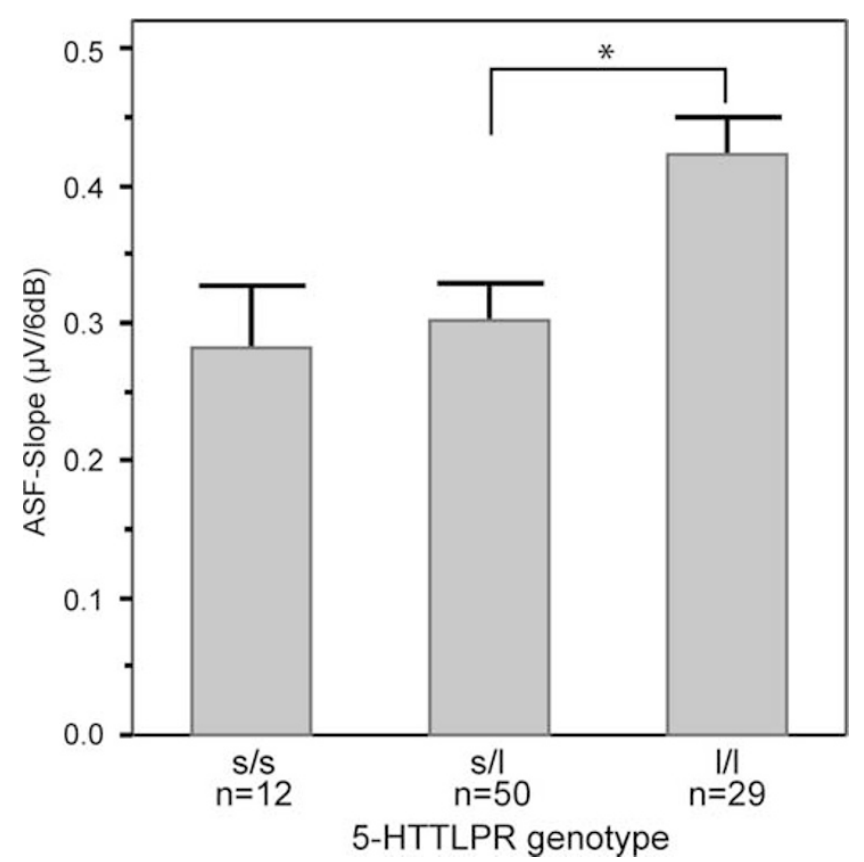

Figure 2 Mean values and SE of the ASF slope at central sites (Cz, C3, C4) for the three 5-HTTLPR genotype groups $(s / s, s / l, I / l)$. The $1 / /$ group shows a significantly $(*)$ higher IAEP than the $s / \mathrm{l}$ group $(p=0.013$; I/I vs $\mathrm{s} / \mathrm{s}$ : $p=0.099 ; \mathrm{s} / \mathrm{s}$ vs $\mathrm{s} / \mathrm{l}: \mathrm{p}=1.000$ ).

Additionally, all analyses were repeated with 5-HTTLPR grouped in terms of functional dominance (s/s and $\mathrm{s} / \mathrm{l} v \mathrm{~s} \mathrm{l} / \mathrm{l}$; Lesch et al, 1996). This did not change the overall pattern of results, but improved the significance levels; for example, 5-HTTLPR main effect with functional dominance: ASF slope: $\mathrm{F}_{1,88}=9.663 ; p=0.003$; median slope: $\mathrm{F}_{1,88}=10.952$; $p=0.001$.

It was possible to retest 18 subjects using the same paradigm 3 weeks later. Although the sample size at $\mathrm{t} 2$ is quite small, it is noteworthy that results were replicated. The main effect for 5-HTTLPR became significant in analyses using ASF slopes $\left(\mathrm{F}_{2,14}=5.379 ; p=0.018\right)$, median slopes $\left(\mathrm{F}_{2,14}=3.852 ; p=0.046\right)$, and area-based slopes (area of ASF slope: $\mathrm{F}_{2,14}=4.639 ; p=0.028$; area of median slope: $\mathrm{F}_{2,14}=6.187 ; p=0.012$ ). Using repeated measurement over the six tone intensities instead of slopes, only dominant genotype classification reached significance level at t2 (peaks: $\mathrm{F}_{5,75}=3.046 ; p=0.015$; areas: $\mathrm{F}_{2.5,38.2}=4.631$; $p=0.010)$.

\section{DISCUSSION}

The present study confirms the association between 5HTTLPR and N1/P2 IAEP, with $1 / 1$ subjects being found to have stronger IAEP in line with the results of Strobel et al (2003). The findings remained significant irrespective of the method of IAEP parametrization ( $A S F$ and median slopes based on peaks or on the area under the curve; repeated measurement with six intensity levels rather than slope calculations). This also held at retest after 3 weeks in a small subsample. The effect size of about $10 \%$ explained variance ( $11 \%$ for median slope) is similar to the effect size obtained by Strobel et al (15\%) and higher than that found by Gallinat et al (4\%). 
The results are consistent with the dominant short allele effect that has been shown in other studies (eg Gallinat et al, 2003; Lesch et al, 1996). The finding that $1 / 1$ genotype is associated with stronger IAEP is also consistent with other data. Some studies found an association of $1 / 1$ genotype with increased serotonin transporter level (van Dyck et al, 2004), and Pogarell et al (2004) found a positive correlation between IAEP and serotonin transporter density in obsessive compulsive disorder. Young age and female gender are also related to higher serotonin transporter levels (Hesse et al, 2003; McQueen et al, 1997; Staley et al, 2001) as well as to higher IAEP (Bruneau et al, 1986; Hegerl et al, 1994; Pogarell et al, 2004). High IAEP and 1/l genotype are both predictors of better SSRI treatment response. Since these results are correlational in nature, however, caution is warranted in making causal interpretations.

The conflicting results reported by Gallinat and associates, on the one hand, and Strobel et al and the present study, on the other, may reflect marked methodological differences, for example, in terms of the intensity ranges used. Very high sound intensities are known to change the IAEP. The highest intensity used in Strobel et al (2003) and in the present study was $96 \mathrm{~dB}$ SPL with a tone duration of $30 \mathrm{~ms}$. Gallinat et al (2003) used a longer tone $(40 \mathrm{~ms})$ with much higher intensities (up to $113 \mathrm{~dB}$ SPL). Thus, the highest intensity in the study by Gallinat and associates is physically about seven times higher than the maximum intensity in the Strobel et al study or in the present study. Intensity levels of about $100 \mathrm{~dB}$ SPL have been shown to lead to paradoxical reductions in evoked potentials and to impact on the linear regression slopes of IAEP (Brocke et al, 1999; Orlebeke et al, 1989; Prescott et al, 1984). This phenomenon has been interpreted as a protection mechanism against overstimulation. Therefore, one can assume that subjects with a steep IAEP within moderate intensity ranges could reach the point of paradoxical reductions in evoked potentials at high intensities earlier, while subjects with a low IAEP within moderate intensities could still have a linear increase in potential within high intensities. Consequently, it cannot ruled out that differences between subjects are totally reversed: high IAEP subjects at moderate intensities could become low IAEP subjects at high intensities and vice versa. Davis et al (1983) have theoretically discussed this possibility, namely that high IAEP subjects could become low ones depending on intensity used. Similar conclusions were also drawn by Prescott et al (1984) from an experiment with an intensity range from 70 to $100 \mathrm{~dB}$ SPL: 'In fact if $90 \mathrm{~dB}$ had been the maximum intensity, the classification of augmenters (ie high IAEP) and reducers (ie low IAEP) would have been reversed!' (p 38). As Prescott et al (1984) did not calculate slopes but did dichotomous classifications ('augmenter' $v s$ 'reducer'), their results cannot be directly compared with this study, but they underline the possible importance of intensity range.

Differences in the populations tested might also explain the conflicting results. In Strobel et al, a young population of university students and staff, including more women than men, was examined (mean age $=21$ years; $\mathrm{SD}=3.0 ; 35$ women, $25 \mathrm{men}$ ). In the study by Gallinat and associates, there were slightly more men than women (96:89) and subjects were much older (mean age $=39 ; \mathrm{SD}=13$ ). IAEP values were only residualized for age and gender influences in Strobel et al. Since age and gender correlate with IAEP, serotonergic function, and serotonin transporter function (see Methods) and because gender can even invert 5-HTTLPR effects (Sjöberg et al, 2005; Williams et al, 2003), the results of these two studies cannot easily be compared. Regarding gender differences, the successful replication of Strobel et al could mean either that statistic control of gender effects carried out in Strobel et al is sufficient, or that there are no significant gender effects on the results.

Further known moderators of the effects of allelic variation of serotonin transporter function are environmental influences and socioeconomic status. The student samples in Strobel et al and the present study might differ in terms of these moderators from a sample of, for instance, paid nonacademic participants recruited via newspaper advertisements (as was the case in Gallinat and associates). Mostly nonacademic paid subjects recruited via newspaper advertisements might not only differ in test anxiety (due to unfamiliar university and laboratory surroundings) but might also differ in socioeconomic status. Belonging to a lower socioeconomic group, they will probably also vary in health, nutrition, early adversity and early environmental enrichment. These factors could contribute to systematic differences in serotonergic neurotransmission, 5-HTTLPR effects and EEG parameters. Early adversity affects the influence of 5-HTTLPR on serotonergic function, psychological vulnerability, and stress reactivity (Barr et al, 2004 a, b; Bennett et al, 2002; Caspi et al, 2003; Kendler et al, 2005; Suomi, 2003). Furthermore, in a study by Kaufman et al (2004), the interaction between maltreatment and 5-HTTLPR s/s genotype had little impact on depression scores if social support was available. These interactions with environmental variables may be one reason for the socio-economic influences observed on 5-HTTLPR effects (Manuck et al, 2004, 2005; Williams et al, 2003).

Taking these modulating factors into account may well explain some of the contradictory findings from 5-HTTLPR research. The aim of this study was two-fold: First, we wanted to show if it is possible to replicate any effect of 5-HTTLPR on IAEP when all the confounding variables which could produce artificial findings are controlled. Secondly, we wondered whether these results were stable over different parametrizations. Both questions have been answered successfully. The noteworthy effect sizes found in the present study, the stability of results over 3 weeks and the replication of the Strobel et al findings irrespective of the method of IAEP parametrization are encouraging. Now further studies should systematically analyze the effects of gender, age, socioeconomic status, and most of all, intensity range (dose) on results. Such a research program will show if IAEP results are dose dependent and if results are generalizable to other populations. The generalizability of the current study is limited due to the sample homogeneity.

Since a broad range of behavioral correlates of both IAEP and 5-HTTLPR have been identified in recent years, with implications for both basic research and pharmacological interventions, further investigation of the inter-relations between these two fields of research is likely to improve our understanding of IAEP and 5-HTTLPR. 


\section{ACKNOWLEDGEMENTS}

This work was supported by the Deutsche Forschungsgemeinschaft (KFO 125/1-1) and the European Commission (NEWMOOD LSHM-CT-2003-503474), and (to LO) by the Swedish Res Council and the Mobilisation Against Narcotics and AFA Foundations. Parts of these results have been reported in a conference abstract (Hensch et al, 2005).

\section{REFERENCES}

Amin Z, Canli T, Epperson CN (2005). Effect of estrogen-serotonin interactions on mood and cognition. Behav Cogn Neurosci Rev 4: 43-58.

Ansorge MS, Zhou M, Lira A, Hen R, Gingrich JA (2004). Early-life blockade of the 5-HT transporter alters emotional behavior in adult mice. Science 306: 879-881.

Barr CS, Newman TK, Lindell S, Shannon C, Champoux M, Lesch KP et al (2004a). Interaction between serotonin transporter gene variation and rearing condition in alcohol preference and consumption in female primates. Arch Gen Psychiatr 61: 1146-1152.

Barr CS, Newman TK, Schwandt M, Shannon C, Dvoskin RL, Lindell SG et al (2004b). Sexual dichotomy of an interaction between early adversity and the serotonin transporter gene promoter variant in rhesus macaques. Proc Natl Acad Sci USA 101: 12358-12363.

Bennett AJ, Lesch KP, Heils A, Long JC, Lorenz JG, Shoaf SE et al (2002). Early experience and serotonin transporter gene variation interact to influence primate CNS function. Mol Psychiatr 7: 118-122.

Bouali S, Evrard A, Chastanet M, Lesch KP, Hamon M, Adrien J (2003). Sex hormone-dependent desensitization of 5-HT1A autoreceptors in knockout mice deficient in the 5-HT transporter. Eur J Neurosci 18: 2203-2212.

Brocke B, Beauducel A, John R, Debener S, Heilemann H (2000). Sensation seeking and affective disorders: characteristics in the intensity dependence of acoustic evoked potentials. Neuropsychobiology 41: 24-30.

Brocke B, Beauducel A, Tasche KG (1999). Biopsychological bases and behavioral correlates of sensation seeking: contributions to a multilevel validation. Pers Indiv Differ 26: 1103-1123.

Bruneau N, Barthelemy C, Jouve J, Lelord G (1986). Frontal auditory-evoked potential augmenting-reducing and urinary homovanillic acid. Neuropsychobiology 16: 78-84.

Camposano S, Lolas F (1992). Effects of stimulation intensity, gender and handedness upon auditory evoked potentials. Arq Neuropsiquiatr 50: 43-49.

Caspi A, Sugden K, Moffitt TE, Taylor A, Craig IW, Harrington $\mathrm{H}$ et al (2003). Influence of life stress on depression: moderation by a polymorphism in the 5-HTT gene. Science 301: 386-389.

Collier DA, Stober G, Li T, Heils A, Catalano M, Di Bella D et al (1996). A novel functional polymorphism within the promoter of the serotonin transporter gene: possible role in susceptibility to affective disorders. Mol Psychiatr 1: 453-460.

Croft RJ, Klugman A, Baldeweg T, Gruzelier JH (2001). Electrophysiological evidence of serotonergic impairment in long-term MDMA ('ecstasy') users. Am J Psychiatr 158: 1687-1692.

Currie PJ, Braver M, Mirza A, Sricharoon K (2004). Sex differences in the reversal of fluoxetine-induced anorexia following raphe injections of 8-OH-DPAT. Psychopharmacology (Berlin) 172: 359-364.

Davis C, Cowles M, Kohn P (1983). Strength of the nervous system and augmenting-reducing: paradox lost. Pers Indiv Differ 4: 491-498.

Debener S, Strobel A, Kurschner K, Kranczioch C, Hebenstreit J, Maercker A et al (2002). Is auditory evoked potential augment- ing/reducing affected by acute tryptophan depletion? Biol Psychol 59: 121-133.

Dierks T, Barta S, Demisch L, Schmeck K, Englert E, Kewitz A et al (1999). Intensity dependence of auditory evoked potentials (AEPs) as biological marker for cerebral serotonin levels: effects of tryptophan depletion in healthy subjects. Psychopharmacology (Berlin) 146: 101-107.

Dominguez R, Cruz-Morales SE, Carvalho MC, Xavier M, Brandao ML (2003). Sex differences in serotonergic activity in dorsal and median raphe nucleus. Physiol Behav 80: 203-210.

Fallgatter AJ, Herrmann MJ, Roemmler J, Ehlis AC, Wagener A, Heidrich A et al (2004). Allelic variation of serotonin transporter function modulates the brain electrical response for error processing. Neuropsychopharmacology 29: 1506-1511.

Fallgatter AJ, Jatzke S, Bartsch AJ, Hamelbeck B, Lesch KP (1999). Serotonin transporter promoter polymorphism influences topography of inhibitory motor control. Int J Neuropsychopharmcol 2: $115-120$

Feinn R, Nellissery M, Kranzler HR (2005). Meta-analysis of the association of a functional serotonin transporter promoter polymorphism with alcohol dependence. Am J Med Genet B Neuropsychiatr Genet 133: 79-84.

Furmark T, Tillfors M, Garpenstrand H, Marteinsdottir I, Langstrom B, Oreland L et al (2004). Serotonin transporter polymorphism related to amygdala excitability and symptom severity in patients with social phobia. Neurosci Lett 362: 189-192.

Gallinat J, Bottlender R, Juckel G, Munke-Puchner A, Stotz G, Kuss $\mathrm{HJ}$ et al (2000). The loudness dependency of the auditory evoked N1/P2-component as a predictor of the acute SSRI response in depression. Psychopharmacology (Berlin) 148: 404-411.

Gallinat J, Senkowski D, Wernicke C, Juckel G, Becker I, Sander T et al (2003). Allelic variants of the functional promoter polymorphism of the human serotonin transporter gene is associated with auditory cortical stimulus processing. Neuropsychopharmacology 28: 530-532.

Gallinat J, Strohle A, Lang UE, Bajbouj M, Kalus P, Montag C et al (2005). Association of human hippocampal neurochemistry, serotonin transporter genetic variation, and anxiety. Neuroimage 26: $123-131$.

Garpenstrand H, Annas P, Ekblom J, Oreland L, Fredrikson M (2001). Human fear conditioning is related to dopaminergic and serotonergic biological markers. Behav Neurosci 115: 358-364.

Gerra G, Garofano L, Zaimovic A, Moi G, Branchi B, Bussandri M et al (2005). Association of the serotonin transporter promoter polymorphism with smoking behavior among adolescents. $A m \mathrm{~J}$ Med Genet B Neuropsychiatr Genet 135: 73-78.

Greenberg BD, Tolliver TJ, Huang SJ, Li Q, Bengel D, Murphy DL (1999). Genetic variation in the serotonin transporter promoter region affects serotonin uptake in human blood platelets. $A m \mathrm{~J}$ Med Genet 88: 83-87.

Halbreich U, Rojansky N, Palter S, Tworek H, Hissin P, Wang K (1995). Estrogen augments serotonergic activity in postmenopausal women. Biol Psychiatr 37: 434-441.

Hariri AR, Drabant EM, Munoz KE, Kolachana BS, Mattay VS, Egan MF et al (2005). A susceptibility gene for affective disorders and the response of the human amygdala. Arch Gen Psychiatr 62: 146-152.

Hariri AR, Mattay VS, Tessitore A, Kolachana B, Fera F, Goldman $D$ et al (2002). Serotonin transporter genetic variation and the response of the human amygdala. Science 297: 400-403.

Hariri AR, Weinberger DR (2003). Functional neuroimaging of genetic variation in serotonergic neurotransmission. Genes Brain Behav 2: 341-349.

Hegerl U, Bottlender R, Gallinat J, Kuss HJ, Ackenheil M, Möller HJ (1998). The serotonin syndrome scale: first results on validity. Eur Arch Psychiatry Clin Neurosci 248: 96-103. 
Hegerl U, Gallinat J, Juckel G (2001). Event-related potentials. Do they reflect central serotonergic neurotransmission and do they predict clinical response to serotonin agonists? J Affect Disord 62: 93-100.

Hegerl U, Gallinat J, Mrowinski D (1994). Intensity dependence of auditory evoked dipole source activity. Int J Psychophysiol 17: $1-13$.

Hegerl U, Gallinat J, Mrowinski D (1995). Sensory cortical processing and the biological basis of personality. Biol Psychiatr 37: 467-472.

Hegerl U, Juckel G (1993). Intensity dependence of auditory evoked potentials as an indicator of central serotonergic neurotransmission: a new hypothesis. Biol Psychiatr 33: 173-187.

Heinz A, Braus DF, Smolka MN, Wrase J, Puls I, Hermann D et al (2005). Amygdala-prefrontal coupling depends on a genetic variation of the serotonin transporter. Nat Neurosci 8: 20-21.

Hensch T, Wargelius HL, Oreland L, Brocke B (2005). A functional polymorphism of the serotonin transporter gene is associated with intensity dependence of auditory evoked potential. J Psychophysiol 19: 121.

Hesse S, Barthel H, Murai T, Müller U, Müller D, Seese A et al (2003). Is correction for age necessary in neuroimaging studies of the central serotonin transporter? Eur J Nucl Med Mol Imaging 30: 427-430.

Holmes A, Yang RJ, Lesch KP, Crawley JN, Murphy DL (2003). Mice lacking the serotonin transporter exhibit 5-HT(1A) receptor-mediated abnormalities in tests for anxiety-like behavior. Neuropsychopharmacology 28: 2077-2088.

Juckel G, Gallinat J, Riedel M, Sokullu S, Schulz C, Möller HJ et al (2003). Serotonergic dysfunction in schizophrenia assessed by the loudness dependence measure of primary auditory cortex evoked activity. Schizophr Res 64: 115-124.

Juckel G, Hegerl U, Molnar M, Csepe V, Karmos G (1999). Auditory evoked potentials reflect serotonergic neuronal activity - a study in behaving cats administered drugs acting on 5-HT1A autoreceptors in the dorsal raphe nucleus. Neuropsychopharmacology 21: 710-716.

Juckel G, Mavrogiorgou P, Bredemeier S, Gallinat J, Frodl T, Schulz C et al (2004). Loudness dependence of primary auditory-cortexevoked activity as predictor of therapeutic outcome to prophylactic lithium treatment in affective disorders - a retrospective study. Pharmacopsychiatry 37: 46-51.

Juckel G, Molnar M, Hegerl U, Csepe V, Karmos G (1997). Auditory-evoked potentials as indicator of brain serotonergic activity-first evidence in behaving cats. Biol Psychiatr 41: 1181-1195.

Kähkönen S, Jaaskelainen IP, Pennanen S, Liesivuori J, Ahveninen J (2002). Acute tryptophan depletion decreases intensity dependence of auditory evoked magnetic N1/P2 dipole source activity. Psychopharmacology (Berlin) 164: 221-227.

Kaufman J, Yang BZ, Douglas-Palumberi H, Houshyar S, Lipschitz $\mathrm{D}$, Krystal JH et al (2004). Social supports and serotonin transporter gene moderate depression in maltreated children. Proc Natl Acad Sci USA 101: 17316-17321.

Kendler KS, Kuhn JW, Vittum J, Prescott CA, Riley B (2005). The interaction of stressful life events and a serotonin transporter polymorphism in the prediction of episodes of major depression: a replication. Arch Gen Psychiatr 62: 529-535.

Kremer I, Bachner-Melman R, Reshef A, Broude L, Nemanov L, Gritsenko I et al (2005). Association of the serotonin transporter gene with smoking behavior. Am J Psychiatr 162: 924-930.

Lang UE, Hellweg R, Gallinat J (2005). Association of BDNF serum concentrations with central serotonergic activity: evidence from auditory signal processing. Neuropsychopharmacology 30: 1148-1153.

Lasky-Su JA, Faraone SV, Glatt SJ, Tsuang MT (2005). Metaanalysis of the association between two polymorphisms in the serotonin transporter gene and affective disorders. Am J Med Genet B Neuropsychiatr Genet 133: 110-115.

Lee TW, Yu YW, Chen TJ, Tsai SJ (2005). Loudness dependence of the auditory evoked potential and response to antidepressants in Chinese patients with major depression. J Psychiatr Neurosci 30: 202-205.

Lesch KP, Bengel D, Heils A, Sabol SZ, Greenberg BD, Petri S et al (1996). Association of anxiety-related traits with a polymorphism in the serotonin transporter gene regulatory region. Science 274: 1527-1531.

Lesch KP, Mössner R (1998). Genetically driven variation in serotonin uptake: is there a link to affective spectrum, neurodevelopmental, and neurodegenerative disorders? Biol Psychiatr 44: $179-192$.

Lotrich FE, Pollock BG (2004). Meta-analysis of serotonin transporter polymorphisms and affective disorders. Psychiatr Genet 14: 121-129.

Maciag D, Simpson K, Coppinger D, Lu Y, Wang Y, Lin R et al (in press). Neonatal antidepressant exposure has lasting effects on behavior and serotonin circuitry. Neuropsychopharmacology, retrieved June 17, 2005, from http://www.acnp.org/citations/ NPP060905050093/default.pdf.

Manjarrez G, Hernandez ZE, Robles OA, Gonzalez RM, Hernandez RJ (2001). Developmental impairment of auditory evoked N1/P2 component in rats undernourished in utero: its relation to brain serotonin activity. Brain Res Dev Brain Res 127: 149-155.

Manuck SB, Bleil ME, Petersen KL, Flory JD, Mann JJ, Ferrell RE et al (2005). The socio-economic status of communities predicts variation in brain serotonergic responsivity. Psychol Med 35: 519-528.

Manuck SB, Flory JD, Ferrell RE, Muldoon MF (2004). Socioeconomic status covaries with central nervous system serotonergic responsivity as a function of allelic variation in the serotonin transporter gene-linked polymorphic region. Psychoneuroendocrinology 29: 651-668.

Massey AE, Marsh VR, McAllister-Williams RH (2004). Lack of effect of tryptophan depletion on the loudness dependency of auditory event related potentials in healthy volunteers. Biol Psychol 65: 137-145.

McQueen JK, Wilson H, Fink G (1997). Estradiol-17 beta increases serotonin transporter (SERT) mRNA levels and the density of SERT-binding sites in female rat brain. Brain Res Mol Brain Res 45: $13-23$.

Milak MS, Ogden RT, Vinocur DN, Van Heertum RL, Cooper TB, Mann JJ et al (2005). Effects of tryptophan depletion on the binding of [11C]-DASB to the serotonin transporter in baboons: response to acute serotonin deficiency. Biol Psychiatr 57: 102-106.

Moreno FA, Rowe DC, Kaiser B, Chase D, Michaels T, Gelernter J et al (2002). Association between a serotonin transporter promoter region polymorphism and mood response during tryptophan depletion. Mol Psychiatr 7: 213-216.

Nilsson KW, Sjöberg RL, Damberg M, Alm PO, Öhrvik J, Leppert J et al (2005). Role of the serotonin transporter gene and family function in adolescent alcohol consumption. Alcohol Clin Exp Res 29: 564-570.

Nishizawa S, Benkelfat C, Young SN, Leyton M, Mzengeza S, de Montigny C et al (1997). Differences between males and females in rates of serotonin synthesis in human brain. Proc Natl Acad Sci USA 94: 5308-5313.

Orlebeke JF, Kok A, Zeillemaker CW (1989). Disinhibition and the processing of auditory stimulus intensity: an ERP-study. Pers Indiv Differ 10: 445-451.

Perna G, Favaron E, Di Bella D, Bussi R, Bellodi L (in press). Antipanic efficacy of paroxetine and polymorphism within the promoter of the serotonin transporter gene, retrieved June 17, 2005, from http://www.acnp.org/citations/NPP060905040461/ default.pdf. 
Pezawas L, Meyer-Lindenberg A, Drabant EM, Verchinski BA, Munoz KE, Kolachana BS et al (2005). 5-HTTLPR polymorphism impacts human cingulate-amygdala interactions: a genetic susceptibility mechanism for depression. Nat Neurosci 8: 828-834.

Pogarell O, Tatsch K, Juckel G, Hamann C, Mulert C, Popperl G et al (2004). Serotonin and dopamine transporter availabilities correlate with the loudness dependence of auditory evoked potentials in patients with obsessive-compulsive disorder. Neuropsychopharmacology 29: 1910-1917.

Prescott J, Connolly JF, Gruzelier JH (1984). The augmenting/ reducing phenomenon in the auditory evoked potential. Biol Psychol 19: 31-44.

Proietti-Cecchini A, Afra J, Schoenen J (1997). Intensity dependence of the cortical auditory evoked potentials as a surrogate marker of central nervous system serotonin transmission in man: demonstration of a central effect for the $5 \mathrm{HT} 1 \mathrm{~B} / 1 \mathrm{D}$ agonist zolmitriptan (311C90, Zomig). Cephalalgia 17: 849-854; discussion 799.

Reif A, Lesch KP (2003). Toward a molecular architecture of personality. Behav Brain Res 139: 1-20.

Reist C, Mazzanti C, Vu R, Tran D, Goldman D (2001). Serotonin transporter promoter polymorphism is associated with attenuated prolactin response to fenfluramine. Am J Med Genet 105: 363-368.

Roon KI, Sandor PS, Schoonman GG, Lamers FP, Schoenen J, Ferrari MD et al (1999). Auditory evoked potentials in the assessment of central nervous system effects of antimigraine drugs. Cephalalgia 19: 880-885.

Rubinow DR, Schmidt PJ, Roca CA (1998). Estrogen-serotonin interactions: implications for affective regulation. Biol Psychiatr 44: 839-850.

Schinka JA, Busch RM, Robichaux-Keene N (2004). A metaanalysis of the association between the serotonin transporter gene polymorphism (5-HTTLPR) and trait anxiety. Mol Psychiatr 9: 197-202.

Schwerdtfeger A, Baltissen R (1999). Kortikale und autonome Reaktivität auf weißes Rauschen unterschiedlicher Intensität in Abhängigkeit vom Persönlichkeitsmerkmal Augmenting-Reducing [Augmenters $v s$ reducers: cortical and autonomic reactivity in response to increasing stimulus intensity]. Zeitschrift für Differentielle und Diagnostische Psychologie 20: 247-262.

Sen S, Burmeister M, Ghosh D (2004). Meta-analysis of the association between a serotonin transporter promoter polymorphism (5-HTTLPR) and anxiety-related personality traits. Am J Med Genet B Neuropsychiatr Genet 127: 85-89.

Seth P, Cheeta S, Tucci S, File SE (2002). Nicotinic-serotonergic interactions in brain and behaviour. Pharmacol Biochem Behav 71: 795-805.

Silverman J, Buchsbaum M, Stierlin H (1973). Sex differences in perceptual differentiation and stimulus intensity control. J Pers Soc Psychol 25: 309-318.

Siniatchkin M, Kropp P, Neumann M, Gerber W, Stephani U (2000). Intensity dependence of auditory evoked cortical potentials in migraine families. Pain 85: 247-254.

Sjöberg RL, Nilsson KW, Nordquist N, Öhrvik J, Leppert J, Lindström L et al (2005). Development of depression: Sex and the interaction between environment and a promoter polymorphism of the serotonin transporter gene. Int J Neuropsychopharmacol, 15 September 2005 [E-pub ahead of print, at http://journals.cambridge.org/action/displayAbstract?fromPage = online\&aid $=336525 \#$.

Smith GS, Lotrich FE, Malhotra AK, Lee AT, Ma Y, Kramer E et al (2004). Effects of serotonin transporter promoter polymorphisms on serotonin function. Neuropsychopharmacology 29: 2226-2234.

Smits KM, Smits LJ, Schouten JS, Stelma FF, Nelemans P, Prins MH (2004). Influence of SERTPR and STin2 in the serotonin transporter gene on the effect of selective serotonin reuptake inhibitors in depression: a systematic review. Mol Psychiatr 9: 433-441.

Staley JK, Krishnan-Sarin S, Zoghbi S, Tamagnan G, Fujita M, Seibyl JP et al (2001). Sex differences in [123I]beta-CIT SPECT measures of dopamine and serotonin transporter availability in healthy smokers and nonsmokers. Synapse 41: 275-284.

Strobel A, Debener S, Schmidt D, Hünnerkopf R, Lesch KP, Brocke B (2003). Allelic variation in serotonin transporter function associated with the intensity dependence of the auditory evoked potential. Am J Med Genet B Neuropsychiatr Genet 118: 41-47.

Suomi SJ (2003). Gene-environment interactions and the neurobiology of social conflict. Ann NY Acad Sci 1008: 132-139.

Tauscher J, Verhoeff NP, Christensen BK, Hussey D, Meyer JH, Kecojevic A et al (2001). Serotonin 5-HT1A receptor binding potential declines with age as measured by [11C]WAY-100635 and PET. Neuropsychopharmacology 24: 522-530.

Tuchtenhagen F, Daumann J, Norra C, Gobbele R, Becker S, Pelz S et al (2000). High intensity dependence of auditory evoked dipole source activity indicates decreased serotonergic activity in abstinent ecstasy (MDMA) users. Neuropsychopharmacology 22: 608-617.

van Dyck CH, Malison RT, Staley JK, Jacobsen LK, Seibyl JP, Laruelle $\mathrm{M}$ et al (2004). Central serotonin transporter availability measured with [123I]beta-CIT SPECT in relation to serotonin transporter genotype. Am J Psychiatr 161: 525-531.

Walpurger V, Pietrowsky R, Kirschbaum C, Wolf OT (2004). Effects of the menstrual cycle on auditory event-related potentials. Horm Behav 46: 600-606.

Whale R, Quested DJ, Laver D, Harrison PJ, Cowen PJ (2000). Serotonin transporter (5-HTT) promoter genotype may influence the prolactin response to clomipramine. Psychopharmacology (Berlin) 150: 120-122.

Willeit M, Stastny J, Pirker W, Praschak-Rieder N, Neumeister A, Asenbaum $S$ et al (2001). No evidence for in vivo regulation of midbrain serotonin transporter availability by serotonin transporter promoter gene polymorphism. Biol Psychiatr 50: 8-12.

Williams RB, Marchuk DA, Gadde KM, Barefoot JC, Grichnik K, Helms MJ et al (2003). Serotonin-related gene polymorphisms and central nervous system serotonin function. Neuropsychopharmacology 28: 533-541.

Yatham LN, Liddle PF, Shiah IS, Lam RW, Adam MJ, Zis AP et al (2001). Effects of rapid tryptophan depletion on brain 5-HT(2) receptors: a PET study. Br J Psychiatr 178: 448-453.

Zuckerman M (1994). Behavioral expressions and biosocial bases of sensation seeking. Cambridge University Press: Cambridge. 